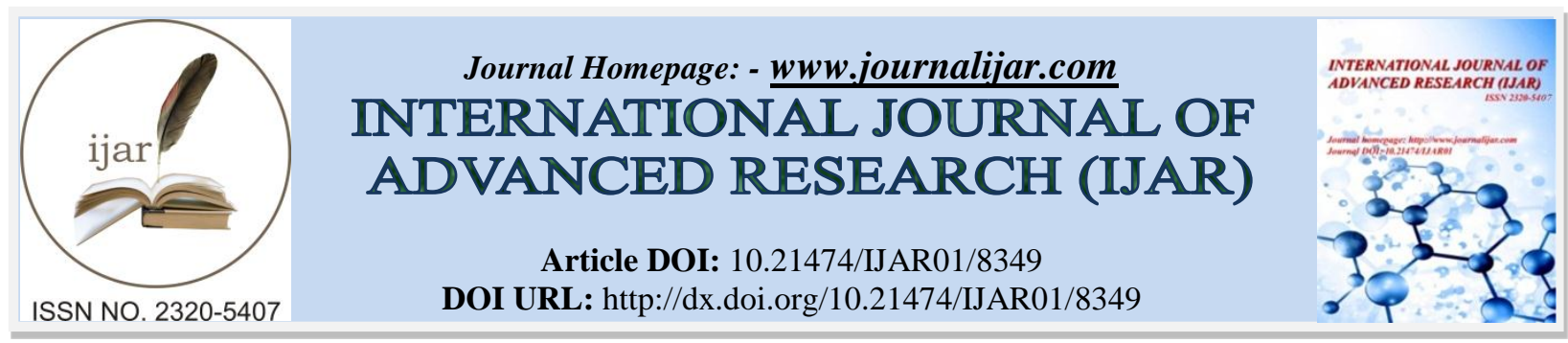

RESEARCH ARTICLE

\title{
ORAL PERFORMANCE AND PUBLIC SPEAKING: POINTS OF CONVERGENCE AND DIVERGENCE.
}

Gilead nkwain ngam.

Department of english modern letters, higher teacher training college, The university of bamenda, cameroon.

\section{Manuscript Info}

Manuscript History

Received: 08 November 2018

Final Accepted: 10 December 2018

Published: January 2019

\section{Key words:-}

oral performance, public speaking, convergence, divergence, Aristotle's pillars.

\begin{abstract}
This paper, from an African perspective, seeks to establish points of divergence and convergence between oral performance and public speaking. The essence is to find a concrete base to justify the claim that the skills and expectations of an African oral artist and a public speaker are, by and large, synonymous and that an African oral performer may require only a little effort to pass for a public speaker of universal standards. In the interest of scientific vigour, the paper exploits Aristotle's pillars of public speaking, performance centredness, components of the speech communication process and some elements of the performance theory to establish points of convergence and divergence between some universal standards of public speaking and African oral performance. Besides functioning as an inspiration and encouragement to potential African orators, the result of the comparison on such theoretical grounds will also help to buttress the contention that African oral artistic resources could be exploited to foster public speaking skills in the contemporary world or that an experienced African oral artist is a potential public speaker.
\end{abstract}

Copy Right, IJAR, 2018,. All rights reserved.

\section{Introduction:-}

It has been argued, with literary and historical evidence, that black Africans have always known and practiced public speaking. However, for some reasons, comparatively few of them have attained universal or international prominence in the art. Great authors such as Stephen E. Lucas and online sites that provide information on the world's superstar speakers reveal that the best speakers in the world have hailed, incontestably, from the Western world. Such great speakers include Winston Churchill, Socrates, John F. Kenedy, Adolf Hitler, Martin Luther King Jr., James Baldwin, Mister Roger, Abraham Lincoln, Bill Clinton, Barack Obama, Margaret Thatcher, Frederick Douglass, Patrick Henry, Winston Churchill etc. It is evident from the list of the world's superstar speakers, that America, Europe, Asia and Australia have produced great orators who have left footprints on the sands of time and have become common names in the mainstream discourse of public speaking. The scarcity of Africans as great orators in the international discourse of public speaking may be explained by the late arrival of literacy in Africa and the sluggishness that has characterized the growth of African economy and technology. There is a reason to guess that most of the great speeches made by Africans in the prehistoric period were obviously performed orally and they vanished with the instances of performance. This seems to be a plausible guess given that some Africans who have lived in the modern era such as Nelson Mandela, Koffi Annan, etc. have exploited their formal educational attainments and international exposure via modern information technology to be able to gain universal prominence

Corresponding Author:-Gilead nkwain ngam. ave come to

Address:-Department of english modern letters, higher teacher training college, The university of bamenda, cameroon. 
function as opportunities for contemporary Africans interested in public speaking to gain international prominence in oratory and to rub shoulders with their counterparts in Europe, America, Asia, Australia etc. However, the limited number of African public speakers on the list of gurus with international prominence is still disturbing because it seems to point, erroneously, to the inability of Africans to excel in the art of oratory at a level that can be internationally appreciated.

In a bid to inspire and encourage Africans to cope with the universal paradigms of public speaking, this paper demonstrates points of convergence and divergence between public speaking and African oral performance or a public speaker and an oral performer. The essence of this demonstration is to corroborate our submission in this paper that the artistic and social expectations of the two artists are largely similar and that an African oral artist or performer requires just a little effort to grow into a successful public speaker of international prominence. For the sake of clarity and consistency, public speaking shall be seen in this paper as the act or process of performing by a single speaker to a live audience, a speech that is deliberately structured to inform, persuade and entertain. A speaker who successfully performs this role is normally a public speaker. On the other hand, according to Helen Chukwuma (1981, p.220), an oral performer is "every man and any man or woman sufficiently knowledgeable in the literary traditions of the people and capable of communicating this in an entertaining way to the audience". Kashim Ibrahim Tala (1989, p.28), in a similar light, sees the story performer as "the person who selects the social identity of the story-teller from among the multiple social identities of his social persona". Ruth Finnegan goes on to emphasize that a performer does not just emit spoken words; he/she also plays upon the flexible and remarkable instruments of the voice to exploit a vast range of non-verbalized auditory devices. He/she endeavours to maintain the beauty of rhyme, alliteration, assonance, rhythm and acoustic parallelism. He/she is also conscious of the subtleties of volume, pitch, tempo, intensity, repetition, emphasis, length, dynamics, silence, timbre, onomatopoeia, and the multifarious non-verbal ways. He/she can use sound to convey, for example, character, dialect, humour, irony, atmosphere, or tension (www.journal.oraltradition.org). Oral performers use gestures to vivify narration, the songs, the dance steps, in brief, all elements that give the story stylistic unity and amplitude combined to produce aesthetic charm. African oral performers are therefore artists who entertain, inspire, and educate their audience. They know how to captivate the audience with more than just words. They use gestures, singing, facial expression, and impersonations to arouse the audience.

The crux of this paper is to illustrate with theoretical and practical evidence the points of divergence and convergence between a public speaker and an African oral performer. It will focus on the expectations of a public speaker and an oral artist in actual performance, demographic audience analysis and the context of performance, the speech communication process and a story telling session, testing of the effectiveness of the Aristotle's pillars of public speaking on an African oral performer, paralinguistic communication and gestures.

\section{Some Expectations of a Public Speaker and an African Oral Performer}

The roles of a public speaker and an African oral performer especially an oral tale narrator converge at the levels of the actual speech delivery and the rendition of an oral peace respectively. The public speaker is irrefutably at the centre of the speech delivery and holds the yam and the knife to make or mar the speech. Specifically, in an extemporaneous speech, He/she is expected to improvise and devise strategies to overcome unforeseen challenges that may arise from other components of the speech communication process. He works to be sufficiently audible, uses appropriate gestures, maintains eye contact, creates suspense and adopts a conversational approach if need be. Similarly, at the centre of oral performance, the expectations of an African performer in a live session abundantly overlap with those of a public speaker. According to Ruth Finnegan et al. in The Oral Nature of African Unwritten Literature, an African oral performer is expected to be creative, audible, dramatize to make lively, employ relevant gestures, and use adequate facial expressions, right props, tonal variation, eye contact and dramatic pauses for suspense, the interplay of passion, dignity or humour and receptivity to the reactions of the audience. Finnegan insists that such devices are not mere embellishments but an integral as well as a flexible part of its full realization as a work of art.

It is noticed that the similarities in the expectations of the two artists during performance are striking with little differences mostly in terms of emphasis. While the public speaker insists on a clear and articulate transmission of a message in a manner that is convincing and persuasive, the African oral performer focuses on artistry and improvisation in a manner that is entertaining, couched in the cultural realities of the text and often embedded with moral undertones. Indeed, the two artists are at the centre of action and the success of delivery depends solely on their forces of experience. It can be observed that the two artists converge at the level of activity but diverge at the 
level of objective. While the public speaker pays more attention to information and persuasion, the oral artist pays more attention to artistry and entertainment

\section{Audience Analysis and the Context of Performance}

Richard Nordquist has defined audience analysis as "the process of determining the values, interests and attitudes of the intended or projected listeners or readers" <https://www.thoughtco.com >>. Audience analysis involves identifying the audience and adapting a speech to their interests, level of understanding, attitudes, and beliefs. Besides the situational analysis of an audience, there is also the demographic analysis which considers elements such as age, sex, education, religion, race etc. and the psychographic analysis which has to do with the beliefs and values of the audience. In public speaking, the success of a speech depends largely on the proper analysis of the audience. Proper situational, demographic and psychographic information about the audience can enhance the effectiveness of the speaker and consequently result in a successful speech. An audience analysis enables a public speaker to situate a speech within a context that is comparable to the context of performance in African oral performances. The context of performance refers to a set of conditions both internal and external which mediate, support and influence someone's performance. These conditions may be cultural, physical, social, personal and temporal.

In a commentary on oral performance, Bronislaw Malinowski in 1926 submits as follows:

The text of course is extremely important, but without context it remains lifeless. As we have seen, the interest of the story is vastly enhanced and it is given its proper character by the manner in which it is told. The whole nature of the performance, the voice and mimicry, the stimulus and the response of the audience mean as much to the natives as the text; and the sociologist should take his cue from the natives. The performance again has to be placed in its proper time-setting-the hour of the day, and the season, gardens awaiting future work and fairy tales. We should also bear in mind the sociological context of private ownership, the sociable function and the cultural role of amusing fiction. All these elements are equally relevant: All must be studied as well as the text. (qtd. by Bascom, 198, pp. 163-172)

In the following quotation, Chakrapani Ghanta also highlights the insistence by African scholars on the crucial role ethnographic features have on the success of oral narratives:

African scholar Russel H. Kaschula emphasises that one should locate the oral narratives from an impartial ethnographic perpective, "ethnographers have long since realised that oral performances cannot be divorced from the socio-political contexts in which they take place". Oral historian Isidore Okpewho states that this approach brough a welcome change to oral literary studies, because it ultimately aimed at representing social man in a creative capacity within the context of a system of signs recognized by his community. Similarly, communicative and performative anthropologist Ruth Finnegan states that "[w]e are now more sensitized to the importance of looking to the 'communicative event' and its inner dynamics as a whole, to the constructive interaction of many participants ... and to a whole range of non-verbal as well as verbal stylistics ... and of ways in which 'performance' may need to be seen not as an 'extra' to the poetic genre but as part of its essence". (http://www.alternatives.ca/ article4180.html)

Scholars of oral literature have continued to see the need for a careful study of the physical as well as the cultural circumstances in which tales are performed. This is based on the fact that the performance context emphasizes the physical elements of performance - comments and questions by members of the audience as well as the performer's dramatization of the various modes and actions described in the text of a story (Okpewho, 1990, p.42).

We can safely conclude here that successful performances of the two artists depend on a similar context. While the public speaker and the African oral performer depend on situational, demographic and psychographic information for a successful rendition, the African oral performer exploits the same requirements for ethno poetic gains and perhaps moral edification. Once more, it is noticed that while the public speaker exploits his context to avoid any kind of embarrassment and to ensure effective communication, the African oral performer sees the same context as an element of aesthetics and an integral part of his massage.

\section{The Speech Communication Process and the Storytelling Session}

The public speaker ensures the success of his speech by consciously coordinating the various components of the speech communication process. The listener, message, situation, medium, channel, feedback and interference as fundamental elements of the speech communication process are managed by the speaker. It is the speaker who analyses the listeners demographically, controls the reality of the situation, ensures that the channel is hitch free, 
stays alert for feedback and works to overcome any challenges that may arise from interference. The centrality of this role is similar to that of an oral tale performer who is equally at the centre of a storytelling session. Helen Chukwuma confirms this central role of a performer when she observes:

The narrator, for effective communication must not only be heard, but seen. The oral tale narration far transcends ordinary verbal communication; it is a dramatic performance with gestures, voice modulations, facial twists, elbow edging, rhythmic leg flexing and other acts, all designed for better communication and to enhance the appeal of the word. (2002, p. 13)

It is also in this light that Philip A. Noss stresses in "The Inside from the Outside: A Student's Approach to Oral Literature" that:

Within the tale there are stylistic devices, aspects of repetition, verbal constructions of rapid consecutive action or simultaneous action, there are idiophones that the performer may use to vivify action or feeling or that he may use to create startling new images, there are comic forms of language that are associated with the hero or the villain, there are oaths, exclamations borrowed from neighboring languages. These and many other artistic devices enable the individual performer to develop his own style of presentation and deliver. (1987, p. 703).

What is evident is the fact that the two artists are at the centre of action. The challenges may be different in that while the public speaker seeks through rhetoric to inform and persuade, the oral performer uses aesthetics to educate, moralize and entertain. However, they converge at the level of their central roles in their separate contexts.

\section{The Effectiveness of Aristotle's Pillars of Public Speaking on African Oral Performance}

In te fourth century Aristotle stated in On Rhetoric, that a successful public speaker is guided by three fundamental pillars namely, pathos, ethos and logos. Scholars in public speaking have agreed that pathos, according to Aristotle, refers to the quality of a persuasive presentation which appeals to the emotions of the audience. A successful speech requires an emotional connection which can be created in many ways by a speaker. An effective use of anecdote, analogy, simile, and metaphor is, often, to link an aspect of our primary message which normally triggers an emotional response from the audience. It is this quality of the speech that arouses emotions and creates alertness and concentration in the audience. Pathos, of course, comes in to complement the ethos which, according to Aristotle, refers to the credibility of the speaker. The audience normally listens to a speech with a more profound concentration when the speaker is of respectable character, trustworthy and proves to be an authority on the speech topic. A speaker with a questionable character, integrity and authority lacks what it takes to speak convincingly and persuasively and is most likely to deliver an unsuccessful speech. These two pillars also need to be complemented by the Logos which is synonymous with a logical argument. Logos aims at a sensible organization of the message based on facts, statistics and evidence that can contribute to a desired outcome. According to Joanne R. Pompano in an online article entitled, Using Oral Traditions to Improve Verbal and Listening Skills, logos is the appeal to logic or the effort to convince your audience by using logic and reason. This means that an effective argument should include testimonials, surveys and other supporting details to back up the claim or the central objective of the speech. Pompano has observed that Aristotle's pillars of public speaking have continued to influence communication discourse and that they are as relevant today as they were in ancient Greece. Our objective at this point is to demonstrate the inadvertent exploitation of these pillars in African oral performance in order to buttress our central contention in this paper. We contend here that African oral performers especially the storytellers have always exploited Aristotle's pillars to attain successful oral performances and that as experts in the application of the three pillars; they can easily and successfully exploit them to improve on their skills in public speaking. Pompano has explained that a storyteller's tools are words assisted by gestures, singing, facial expressions, body movements and acting. He/she relays information using formats such as narratives, folktales, proverbs, riddles, myths, dance, poetry, praise songs and other devices to enhance their presentation. These strategies combine to create an emotional appeal in the audience which is what Aristotle called pathos in public speaking.

It is evident from this discussion that the pillars of a public speaker as explained by Aristotle are equally fundamental requirements of an African oral performer. The two artists require credibility, ability to appeal to emotions and logical organization of contents. While the public speaker needs the pillars to be able to inform, persuade or convince an audience, the oral performer requires the same ingredients to be able to entertain and transmit traditional values and mores to an audience. The degree of exploitation of the pillars may differ but the pillars remain the same. Given that the oral artist has, as a primary objective, to attain aesthetic beauty, the use of pathos and logos are exploited to a higher degree. According to Pompano, the oral artist gives a great deal of 
emphasis to rhythm and repetition. He/she repeats words, phrases, refrains, whole lines and even stanzas often with the intention of achieving artistic beauty and drawing attention to situations and events.

\section{Paralinguistic Communication and Gestures}

Meaning lies beyond simple lexis. In other words, there is communication outside of the words themselves. Volume, pitch, intonation and speed tend to emphasize or add shades of meaning to what people say. These changes in the voice plus facial expressions, body gestures, tone are crucial to a public speaker. When these paralinguistic features are carefully exploited, they play a significant role to a good public speaker who is at the centre of the speech communication process. They normally help to convey meaning emphatically and forcefully. In Paralinguistic as an Expression of Communicative Behaviour, L. Spasova notes that an etiquette presenter pays attention to haircut; make up, way of dress and timbre of the voice to emphasize meaning. These paralinguistic communicative elements are also fundamental in oral performance. Pompano has emphasized this similarity by noting that the storyteller's tools are words assisted by gestures, singing, facial expressions, body movements and acting to make a story more memorable and interesting.

The importance of public speaking in the contemporary world needs not be overemphasized. All actors in the current socio-political life require a certain level of the knowledge of public speaking. Religious leaders, preachers, teachers, politicians, researchers, managers, directors, students, peace negotiators, health officials etc; need to attain an appreciable level of public speaking. Consequently, public speaking is more and more gaining grounds in most universities as an essential subject of academic discipline. On the basis of this reality, any research in African studies that is aimed at developing and encouraging Africans in the art of public oratory should be of great import. Given the universal and the imposing need for knowledge of public speaking, this paper has demonstrated that contemporary African oral artists could exploit African oral artistic resources and transform them into competences in the universal standards of public speaking. The points of convergence between public speaking and oral performance illustrated in this paper have, hopefully, buttressed the contention that African oral performers, especially the oral narrators could easily pass for public speakers. An African oral artist, like a public speaker, possesses similar expectations during an actual performance. His context of performance tallies with the demographic audience analysis expected to be carried out by the public speaker before the speech. The components of the speech communication process for the public speaker are akin to the African oral narrator in a story telling session. The Aristotle's pillars which are fundamental in public speaking are evidently applicable for a successful African oral performance. Above all, paralinguistic communication and gestures are essential requirements for both the African oral performer and the public speaker. Evidently, the former could easily pass for the latter.

\section{References:-}

1. Chukwuma, H.O. The Oral tale, Odense. Port Harcourt, Pearl Publishers, 1988.

2. Finnegan, Ruth et al. The Oral Nature of African Unwritten Literature. Cambridge, Open Book Publishers, 2014.

3. Ghanta, Chakrapani. "Oral Literature in Translation” http://www.alternatives.ca/article4180.html 2008, accessed 8/29/2009.

4. Lucas, S. E. The Art of Public Speaking. New York, McGraw-Hill Education, 2009.

5. Malinowski, B. Myth in Primitive Psychology. New York, w.w. Norton and CO. 1926.

6. Nordquist, Richard. Audience Analysis in Speech. <https://www.thoughtco.com> 2009 accessed 10 June 2018.

7. Noss, P.A. Translation and African Oral Tale. Black Culture and Black Consciousness in Literature, ed. Ernest N. Emenyon, 1987.

8. Okpewho, Isidore. African Oral Literature: Background, Character and Continuity. Bloomington, Indiana University Press.

9. Pompano, J.R. Using Oral Traditions to Improve Verbal and Listening Skills. <teacherinstitute.yale.edu/curriculum/units> 2005 accessed 15 April 2018.

10. Tala, K.I. The Oral Tale in Africa. Yaounde, BET and CO. (Pub), 1989. 